\title{
ANALISIS PERAN WALI KELAS DALAM PEMBELAJARAN DARING SELAMA PANDEMI COVID-19 PADA SMK HASANUDDIN MEDAN
}

\author{
ANALYSIS OF THE ROLE CLASS PRIVATE IN ONLINE LEARNING DURING \\ COVID-19 PANDEMIC IN SMK HASANUDDIN MEDAN
}

\author{
MUHAMMAD DALIANI ${ }^{1}$, NILAM SARI', VERA DEWI KARTINI OMPUSUNGGU ${ }^{3}$ \\ ${ }^{1}$ Program Studi Pendidikan Matematika, Universitas Quality \\ Jalan Ngumban Surbakti no.18 Medan,email: mddaniboys@gmail.com. \\ ${ }^{2}$ Program Studi Pendidikan Matematika,Universitas Quality \\ Jalan Ngumban Surbakti no. 18 Medan, email: nilamsarie@gmail.com. \\ ${ }^{3}$ Program Studi Pendidikan Matematika,Universitas Quality \\ Jalan Ngumban Surbakti no.18 Medan, email: verakartini@gmail.com.
}

\begin{abstract}
Abstrak
Dampak dari pembelajaran daring yang terjadi akibat surat edaran dari Menteri Pendidikan dan Kebudayaan nomor: 36962/MPK.A/HK/2020 tertanggal 17 Maret 2020 tentang pembelajaran secara daring dan bekerja dari rumah dalam rangka pencegahan penyebaran Covid. Hal ini membuat kesulitan para guru terutama wali kelas dan orang tua dalam mengawasi peserta didik mengikuti pembelajaran. Selain peran orang tua yang selalu mendidik dan mengawasi anaknya dirumah untuk mengikuti pembelajaran secara daring ada juga peran Wali Kelas yang harus ekstra mengawasi peserta didik dari sekolah. Sehingga penelitian ini dibuat untuk mengetahui peran dan tugas wali kelas dalam pembelajaran daring serta kendala yang tejadi didalam pembelajaran tersebut. Penelitian yang digunakan merupakan jenis penelitian deskriptif kualitatif. Teknik pengumpulan datanya diperoleh dari wawacara, dokumentasi dan kuesioner. subjek penelitian terdiri atas 3 sampel wali kelas dan sebagai responden berjumlah 35 orang yaitu kepala sekolah, pembantu kepala sekolah kurikulum, bimbingan konseling, 2 orang teman sejawat, 15 orang siswa dan 15 orang wali siswa. Prosedur penelitiannya dilakukan secara online menggunakan Google Form. Kemudian data tersebut dianalisis melalui tahap reduksi data, penyajian data dan penarikan kesimpulan. Penelitian menunjukkan bahwa peran wali kelas selama pembelajaran daring dalam pengelolaan kelas sudah berjalan dengan baik dan perlu ditingkatkan lagi agar mencapai tujuan secara efektif dan efisien sesuai yang diinginkan. Adapun kendala yang dihadapi oleh wali kelas adalah harus lebih teliti, rajin mengawasi dan bertanya kepada setiap guru bidang studi permasalahan siswa yang tidak aktif (kehadiran dan tugas), harus mengunjungi rumah siswa yang bermasalah dan adasiswa/siswi yang tidak mau mendengar ataupun mematuhinya.
\end{abstract}

Kata kunci : Peran Wali Kelas, Tugas Wali Kelas, Pembelajaran Daring

\begin{abstract}
The impact of online learning that occurred due to a circular from the Minister of Education and Culture number: 36962 / MPK.A / HK / 2020 dated 17 March 2020 regarding online learning and working from home in order to prevent the spread of Covid. This makes it difficult for teachers, especially homeroom teachers and parents, in supervising students following learning. Apart from the role of parents who always educate and supervise their children at home to take part in online learning, there is also the role of the homeroom teacher who has to be extra supervising students from school. So this research was made to determine the role and duties of the homeroom teacher in online learning as well as the obstacles that occur in learning. The research used is a descriptive qualitative research type. Data collection techniques were obtained from interviews, documentation and questionnaires. Research subjects consisted of 3 samples of homeroom teachers and 35 respondents as respondents, namely the principal, assistant principal of the curriculum, counseling, 2 peers, 15 students and 15 guardians. The research procedure was carried out online using Google Form. Then the data is analyzed through the data reduction stage, data presentation and drawing conclusions. Research shows that the role of homeroom teacher during online learning in class management is already going well and needs to be improved again in order to achieve the goals effectively and efficiently as desired. The obstacles faced by the homeroom teacher are having to be more careful, diligent in monitoring and asking each teacher in the field of study of student problems who are inactive (attendance and assignments), having to visit the homes of students who have problems and there are students/students who do not want to hear or obey them.
\end{abstract}

Keywords: The role of homeroom teacher, homeroom teacher, online learning. 


\section{Pendahuluan}

Terkait dengan hal pendidikan, Depdiknas RI dalam undang-undang No. 20 Tahun 2003 tentang sistem pendidikan Nasional pasal 1 ayat 1 dijelaskan bahwa, "Pendidikan adalah usaha sadar yang terencana untuk mewujudkan suasana belajar dan proses pembelajaran agar peserta didik secara aktif mengembangkan potensi dirinya untuk memiliki kekuatan spiritual keagamaan, pengendalian diri, kepribadian, kecerdasan, akhlak mulia, serta keterampilan yang diperlukan dirinya, masyarakat, bangsa dan Negara". Oleh karena itu, keberadaan pendidikan dalam kehidupan ini dapat dipandang sebagai sesuatu yang paling bermakna dibandingkan dengan aktivitas lainnya. Salah satu upaya yang dapat dilakukan untuk meningkatkan sumber daya manusia adalah peningkatan mutu pendidikan, baik prestasi belajar siswa maupun kemampuan guru dalam melaksanakan proses pembelajaran. Peningkatan mutu pendidikan diarahkan untuk meningkatkan kualitas manusia seutuhnya melalui olah hati, olah rasa, dan ulah raga agar memiliki daya saing dalam menghadapi tantangan global[1].

Pembelajaran yang berlangsung di sekolah merupakan proses interaksi antara guru, siswa, kurikulum, sarana pembelajaran, media pembelajaran, dan komponen lain yang berpengaruh pada proses belajar mengajar untuk mencapai tujuan pembelajaran yang diharapkan[2]. Akan tetapi akibat terjadinya musibah diseluruh dunia pada awal 2020 yaitu musibah virus corona. Virus corona atau severe acute respiratory syndrome corona virus 2 (SARS-CoV-2) adalah virus yang menyerang sistem pernapasan. Penyakit karena infeksi virus ini disebut COVID-19. Hal ini membuat beberapa negara di luar negeri menerapkan kebijakan untuk memberlakukan Lockdown, dalam rangka mencegah penyebaran virus corona termasuk juga Indonesia. Sehingga pembelajaran yang berlangsung disekolah juga mengalami kendala. Proses pembelajaran juga dilaksanakan secara online (Pembelajaran Daring) menggunakan aplikasi-aplikasi yang telah ditentukan disekolah masing-masing. Salah satunya Whats App, BBM, telegram, Google Classroom, Zoom, dan Hangouts. Pembelajaran yang berlangsung secara online berpengaruh pada kesadaran keinginan belajar siswa, pantauan peranan orang tua, serta juga pantauan peran wali kelas.

Di sekolah dasar/sederajat dikenal guru kelas. Guru kelas menguasai kelas dengan hampir semua mata pelajaran. Di sekolah menengah pertama/sederajat dan sekolah menengah atas/sederajat proses belajar mengajar disampaikan oleh banyak guru sesuai dengan bidang keahliannya masing-masing. Sehingga satu mata pelajaran akan ditangani oleh satu guru bidang studi. Akan tetapi guru yang memantau, mengelolah, dan mengawasi permasalahan yang ada kelas secara spesifik dikenal istilah Wali Kelas. Wali kelas biasanya mengajarkan salah satu mata pelajaran yang berada dikelas tersebut. Peran wali kelas ini agak lebih spesifik karena melibatkan proses bimbingan secara akademis maupun non-akademis. Peran wali kelas dalam hal ini sangat berpengaruh terhadap perkembangan siswa disekolah, karena wali kelas merupakan orang tua yang selalu memantau, mengawasi didalam lingkungan pendidikan sekolah. Segala permasalahan yang ada, kehadiran, penugasan, serta sopan santun menjadi tanggung jawab wali kelas[3][4]. Sehingga permasalahan kelas yang terjadi dimasa pandemi ini maka pengelolaan kelas juga dipantau secara online. Kesulitan wali kelas dimasa pandemi Covid 19 ini sangatlah komplit, karena harus memantau setiap kehadiran serta tugas siswa didalam mata pelajaran yang berbeda[5][6].

Atas dasar hal tersebut maka dilaksanakanlah penelitian ini dengan judul "Analisis Peran Wali Kelas Dalam Pembelajaran Daring Selama Pandemi Covid 19 Pada SMK Hasanuddin Medan”.Tujuan penelitian ini adalah untuk mengetahui peran wali kelas dalam pengelolaan kelas selama pembelajaran daring dimasa Covid19 dan juga untuk mengetahui kendala-kendala yang dialami wali kelas dalam pengelolaan kelas tersebut.

\section{Metode Penelitian}

Populasi yang dimaksud pada penelitian ini adalah Satuan Unit SMK Hasanuddin Medan yang sedang melakukan pembelajaran daring. Dengan pengambilan Sampel 3 orang Wali Kelas yang harus mengawasi permasalahan siswa dengan responden sebanyak 35 orang yang terdiri atas Kepala Sekolah, Pembantu Kepala Sekolah Kurikulum, guru BK, 2 orang teman sejawat (guru bidang studi), 15 orang siswa dan 15 orang wali siswa.

Penelitian ini merupakan jenis penelitian kualitatif dengan metode deskriptif. Penelitian deskriptif merupakan metode penelitian yang berusaha menggambarkan dan menginterprestasi objek sesuai dengan apa adanya. Teknik pengumpulan datanya diperoleh dari wawacara, dokumentasi dan kuiseoner (angket).

Prosedur penelitiannya dilakukan secara online menggunakan aplikasi Google Form. Hal ini dikarenakan Lockdown (menetap dirumah) sehingga wawancara dilakukan dengan video call dan untuk pemberian kuiseoner juga dikirim dan didata melalui email.

1. Melakukan konversi skorsing data dari kuesioner penilaian analisis peran wali kelas selama pembelajaran daring terhadap siswa. Agar bisa menganalisis data lebih lanjut, setiap jawaban dari kuesioner ini dikonversi skorsing kedalam bentuk numerik. Adapun skor yang diberikan pada setiap pernyataan, untuk pernyataan positif: 
Skor 5 apabila responden menjawab Sangat Setuju

Skor 4 apabila responden menjawab Setuju

Skor 3 apabila responden menjawab Kurang Setuju

Skor 2 apabila responden menjawab Tidak Setuju

Skor 1 apabila responden menjawab Sangat Tidak Setuju

Selanjutnya menghitung frekuensi setiap kategori jawaban dalam masing-masing variabel. Skor yang didapat kemudian dihitung dan memasukannya kedalam rumus deskriptif persentase. Dan konversi skorsing dianalisis dengan menggunakan uji validitas dan realibilitas terhadap peran dan fungsi wali kelas selama covid.

Untuk memperoleh data skala keaktifan peran wali kelas selama pembelajaran daring.Untuk melihat peningkatan (N-gain) dengan rumus:

$$
D p=\frac{n}{N} \times 100 \%
$$

Keterangan:

$D p=$ Skor yang diharapkan

$\mathrm{N}=$ Jumlah skor maksimal

$n \quad=$ Jumlah skor yang diperoleh

Selanjutnya dari hasil analisis deskriptif kemudian dibuat keputusan, apakah wali kelas telah melaksanakan peranannya sebagai wali kelas selama pembelajaran daring sangat tinggi, tinggi, sedang, rendah atau sangat rendah.

Analisis data menggunakan teknik deskriptif kualitatif memanfaatkan persentase hanya merupakan langkah awal saja dari keseluruhan proses analisis. Analisis kualitatif tentu harus dinyatakan kedalam sebuah predikat yang menunjuk pada pernyataan keadaan, ukuran kualitas. Berdasarkan hal tersebut, maka hasil perhitungan berupa persentase tersebut diubah menjadi sebuah predikat, antara lain:

$80,1 \%-100,0 \%=$ Sangat tinggi

$60,1 \%-80,0 \%=$ Tinggi

$40,1 \%-60,0 \%=$ Sedang

$20,1 \%-40,0 \%=$ Rendah

$0,0 \%-20,0 \%=$ Sangat rendah

2. Hasil wawancara dengan Wali Kelas dianalisis secara deskriptif untuk mengetahui kendala apa saja yang dialami wali kelas selama pembelajaran daring.

Pada penelitian ini dilakukan melalui beberapa tahap yang diawali dengan studi pendahuluan yang digunakan untuk merumuskan identifikasi masalah, rumusan masalah yang merujuk pada pemilihan pendekatan pembelajaran yang sesuai. Selanjutnya pembuatan instrumen penelitian, analisa instrument dan melakukan validasi oleh pakar yang berkompeten. Tahap selanjutnya penentuan wali kelas sebagai sampel dan siswa, wali murid/orangtua, kepala sekolah, wakil kepala sekolah, bimbingan konseling sebagai responden.Tindakan selanjutnya pengamatan kelokasi sekolah dikarenakan pegawai dan staf disekolah tetap wajib hadir kesekolah meskipun pembelajaran secara daring. Untuk tahapan pemerolehan data, untuk kepala sekolah, wakil kepala sekolah, guru BK dan wali kelas dilakukan dengan tahapan wawancara. Sedangkan untuk siswa dan wali murid/orang tua dilakukan dengan pemberian angket dengan menggunakan google form. Setelah data dianalisa akan diperoleh kesimpulan yang menjadi hasil temuan pada penelitian ini. Berikut adalah diagram alir tahapan demi tahapan yang dilalui dalam penelitian ini beserta tugas dari masing-masing ketua dan anggota pengusul.

\section{Hasil Penelitian dan Pembahasan}

Instrumen yang digunakan untuk menganalisis data pada penelitian ini yaitu berupa angket dan wawancara. Sehingga diuraikan hasil analisis data terhadap peran wali kelas selama covid meliputi deskripsi hasil wawancara peran dan fungsi wali kelas, uji validitas dan realibilitas penskorsingan data peran wali kelas.

Hasil analisis data angket itu diperoleh dari aplikasi google form berupa pernyataan skor 5 menyatakan sangat setuju, skor 4 menyatakan setuju, skor 3 menyatakan kurang setuju, skor 2 menyatakan tidak setuju dan skor 1 menyatakan sangat tidak setuju. Hasil uji coba instrumen angket dianalisis untuk mengetahui validitas dan reliabilitasnya terhadap peran wali kelas. Analisis uji coba instrumen pada penelitian ini menggunakan microsoft excel dan dihitung menggunakan aplikasi SPSS. Hasil perhitungan validitas dan reliabilitas dibahas pada uraian di bawah ini.

Perhitungan uji validitas instrumen angket dilakukan dengan analisis validitas metode bivariate correlation product moment dengan bantuan program statistik SPSS 16 for Windows. Data yang dianalisis diperoleh dari hasil uji instrumen angket peran wali kelas yang terdiri dari 20 butir pernyataan. Ketentuan validasi instrumen diukur berdasarkan kriteria validitas yang menyatakan jika $r$ hitung $\geq r$ tabel maka instrumen dinyatakan valid, 
Hal : $1-6$

tetapi jika rhitung < rtabel maka instrumen dinyatakan tidak valid. Diketahui bahwa $r_{\text {tabel }}$ menggunakan taraf signifikan $\alpha=0,05$ dengan $n=35$, maka diperoleh nilai rtabel sebesar 0,334 . Untuk mempermudah menguji validitas tiap tiapbutir soal pada instrumen angket, peneliti menggunakan bantuan Microsoft excel.

Dari tabeluji validitas diatas menunjukkan bahwa dari 20 item soal yang diperoleh dari angket Google form dan dikelola melalui uji validitas dengan $r_{\text {tabel }}$ menggunakan taraf signifikan $\alpha=0,05$ dengan $n=35$, maka diperoleh nilai rtabel sebesar 0,334 menyatakan rhitung > rtabel sehingga 20 item tesebut semuanya valid.

Penelitian ini harus dilakukannya uji reliabilitas untuk mengukur konsisten atau tidak kuesioner dalam penelitian yang digunakan. Adapun penulis menggunakan uji reliabilitas dengan metode Cronbach's Alpha dengan bantuan statistik SPSS 16 for Windows. Sebelum dilakukannya pengujian reliabilitas harus ada dasar pengambilan keputusanya itu alpha sebesar 0,05. Variabel yang dianggap reliable jika nilai variabel tersebut lebih besar dari >0,05 jika lebih kecil maka variabel yang diteliti tidak bisa dikatakan reliable karena <0,05.

Hasil analisis data wawancara juga diperoleh dari aplikasi google form yang sampaikan berupa hasil chat kolom pertanyaan essai. Adapun hasil analisis sumber responden wawancara yaitu kepala sekolah, dan 3 orang wali kelas.

a. Hasil Analisis Observasi

Dari hasil observasi, penulis telah mendapatkan data mengenai pembelajaran daring menyatakan bahwa:

1. Permasalahan terhadap siswa yang tidak beminat mengikuti pembelajaran daring menjadi tanggung jawab Wali Kelas, hal ini ditunjukkan melalui persentase responden yang berjumlah 35 orang menyatakan 48,6\% menjadi tanggung jawab wali kelas, 14,3\% guru, 5,7\% BK dan $31.4 \%$ yang lainnya (orangtua).

2. Mengenai pendataan ketidakhadiran siswa selama pembelajaran daring merupakan tanggung jawab Guru Bidang Studi, hal ini ditunjukkan dengan grafik $60 \%$ sedangkan yang menyatakan wali kelas hanya $40 \%$.

3. Yang harus menindaklanjuti masalah siswa yang tidak efektif masuk pembelajaran daring yaitu Wali Kelas dengan menunjukkan grafik $80 \%$, sedangkan guru bidang studi hanya $17.1 \%$ dan $\mathrm{BK} 2.9 \%$.

4. Hukuman yang harus diberikan kepada siswa yang tidak mengikuti pembelajaran daring ditunjukkan dengan tingkatan persentase Surat Peringatan Orangtua 31.4\%, disuruh datang kesekolah 22.9\%, hanya ditelpon saja $22.9 \%$, home visit $20 \%$ dan biarkan saja $2.9 \%$.

b. Hasil Analisis Wawancara

Hasil penyajian data yang diperoleh dari wawancara terhadap kepala sekolah dan wali kelas adalah sebagai berikut:

1. Kepala Sekolah SMK Hasanuddin (Bapak Wiwid Kurniandi, S.PdI), menyatakan bahwa "kebijakan yang saya buat adalah wali kelas wajib melakukan pemantauan absensi siswa di kelas online. Wali kelas tetap hadir kesekolah sesuai jadwal yang telah disepakati. Dan peran dan fungsi yang dilakukan wali kelas adalah Wali kelas telah melakukan visitasi dan komunikasi dengan orang tua/wali murid guna memastikan ketersediaan sarana/prasarana pembelajaran dan guna menjalin kerjasama yang efektif, serta wali kelas sebagai agent of control menjaga semangat dan motivasi siswa agar selalu hadir di kelas-kelas daring. Sedangkan stuktural penyelesaian permasalahan siswa selama daring akan ditangani wali kelas terlebih dahulu yang akan melakukan koordinasi dan komunikasi kepada orang tua. Jika tidak terselesaikan di wali kelas, akan ditingkatkan ke guru BP, PKS Kesiswaan dan terakhir ke Kepala Sekolah".

2. Wali Kelas X TKJ/ OTKP (Ibu Rini Siti Jumiah, S.Pd), menyatakan bahwa "sebagai wali kelas harus berperan lebih aktif dalam memotivasi siswa dalam melaksanakan pembelajaran dan sering menghubungi para wali siswa agar selalu mengingatkan untuk selalu belajar, selain itu fungsi wali kelas sendiri harus selalu memeriksa absensi para siswa dan mengecek keaktifkan belajar para siswa tersebut serta langkah langkah mengatasi permasalahan siswa yang tidak aktif dengan cara menguhubungi wali siswa tersebut dan menyuruh siswa tersebut dating ke sekolah, dan jika tidak dapat dihubungi maka mendatangi tempat tinggal siswa tersebut sedangkan kendala hal yang menjadi halangan ketidak aktifan siswa didalam pembelajaran daring adalah terbatasnya para siswa yang menggunakan gawai/gadget serta jaringan internet.".

3. Wali Kelas XI TKJ (Ibu Nurhayati, S.Pd), menyatakan bahwa "peran wali kelas harus terus memotivasi anak tersebut agar tetap semangat belajar di masa pandemi seperti ini walau banyak hambatan yang terjadi akibat belajar secara daring, tapi tetap saya pantau siswa siswi tersebut agar tetap belajar dan aktif seperti biasa, sedangkan fungsi wali kelas itu sendiri selama daring sangat penting untuk membangun motivasi atau semangat dalam diri siswa siswi agar tidak bermalas2an dalam proses pembelajaran secara daring ini serta didalam langkah langkah penanganan masalah bagi siswa yang tidak aktif adalah Berkomunikasi kepada orang tua siswa agar siswa masuk dalam proses pembelajaran dan meminta siswa datang kesekolah untuk menceritakan masalah yang sedang dihadapi siswa agar dapat diselesaikan dan jika tidak ada solusi jalan satu2nya dengan mendatangkan rumah sianak untukmencari tau permasalahannya".

4. Wali Kelas XII TKJ (Ibu Mismaulina Hsb, S.T), menyatakan bahwa "peran wali kelas yaitu berusaha semaksimal mungkin untuk mendata dan mengawasi siswa yang tidak hadir dan tidak mengerjakan tugas 
Hal : $1-6$

sedangkan fungsi wali kelas berusaha selalu mengawasi, menegur, siswa yang tidak aktif di KBM daring dan serta langkah-langkah penanganan masalah siswa yang tidak aktif adalah Tahap pertama menegur siswa dengan menghubungi melalui aplikasi chat, tahap kedua menyuruh datang kesekolah membuat perjanjian, home visit, luring (luar jaringan/ belajar datang kesekolah)".

\section{Pembahasan}

Pembahasan mengenai hasil analisis angket menunjukkan dari uji validitas 20 butir item pertanyaan melalui uji validitas dengan $r_{\text {tabel }}$ menggunakan taraf signifikan $\alpha=0,05$ dengan $n=35$ dinyatakan Valid seluruh item hal ini dikarenakan rhitung > rtabel pada seluruh butir soal. Sedangkan uji realibilitas menunjukkan hasi 0,962sehingga taraf signifikan Alpha 5\% $(0,05)$ maka Cronbach's Alpha 0,962> 0,05 maka semua pernyataan pada variabel ini dinyatakan reliable atau bisa dipercaya. Akan tetapi pada uji realibilitas per item hanya menunjukkan hanya 5 soal item yang menyatakan Valid yaitu soal 1, soal 2, soal 5, soal 19 dan soal 20.

Pembahasan mengenai hasil analisis wawancara (angket pertanyaan) menyatakan bahwa mengenai keaktifan maupun ketidakhadiran siswa seharusnya merupakan tugas guru bidang studi masing masing, akan tetapi didalam penindaklanjutan permasalahan tersebut barulah menjadi tanggung jawab wali kelas. Hal inilah yang menunjukkan bahwa Wali kelas memiliki peran sebagai mitra guru bidang studi dalam artian harus bekerjasama didalam mengkoordinir keaktifan siswa. Setelah diketahui siswa yang bermasalah wali kelas berhak menindaklanjuti permasalahan siswa tersebut. Sesuai pendapat responden bahwa wali kelas memberikan nasehat, memotivasi, menanyakan penyebab permasalahan siswa tersebut, disinilah peran wali kelas sebagai mitra siswa dilaksanakan. Akan tetapi setelah permasalahan terhadap pemanggilan/menasehati siswa tidak berlangsung dengan yang diinginkan maka wali kelas berhak memberikan surat panggilan orangtua (SPO) agar orangtua mengetahui permasalahan siswa tersebut, hal inilah yang menunjukkan peran wali kelas juga sebagai mitra orangtua didalam menyelesaikan permasalahan anaknya. Sehingga dari penyelesaian permasalahan terhadap siswa itu juga belum terselesaikan maka wali kelas akan melaksanakan perannya sebagai pimpinan penengah (middle manage) yaitu memberikan saran dan solusi kepada kepala sekolah. Sehingga kesimpulan dari pernyataan pembahasan hasil analisis diatas menyatakan bahwa peran wali kelas tetap akan diterapkan walaupun pelaksanaan pembelajaran secara daring[7].

Berdasarkan tanggapan responden, adapun kendala yang dihadapi oleh wali kelas adalah harus lebih teliti, rajin mengawasi dan bertanya kepada setiap guru bidang studi permasalahan siswa yang tidak aktif (kehadiran dan tugas), harus mengunjungi rumah siswa yang bermasalah dan adasiswa/siswi yang tidak mau mendengar ataupun mematuhinya (tidak peduli/tidak mengiraukan permasalahannya).

\section{Kesimpulan}

Berdasarkan hasil penelitian tentang peran wali kelas dalam pembelajaran daring selama pandemi covid19, diperoleh beberapa kesimpulan yang merupakan jawaban atas pertanyaan-pertanyaan pada rumusan masalah, diantaranya:

1. Peran wali kelas selama pembelajaran daring dalam pengelolaan kelas sudah berjalan dengan baik dikarenakan peran wali kelas selama daring sama dengan pembelajaran secara tatap muka sehingga tidak ada kesulitannya. Akan tetapi perlu harus lebih ekstra dikarenakan penyampaian permasalahan dan penindaklanjutan agak sulit karena semua hal harus dikontrol dan disampaikan didalam komunikasi tidak langsung.

2. Adapun kendala yang dihadapi oleh wali kelas adalah harus lebih teliti, rajin mengawasi dan bertanya kepada setiap guru bidang studi permasalahan siswa yang tidak aktif (kehadiran dan tugas), harus mengunjungi rumah siswa yang bermasalah dan adasiswa/siswi yang tidak mau mendengar ataupun mematuhinya.

Berdasarkan hasil penelitian dengan peran wali kelas dalam pembelajaran daring selama pandemi covid-19, memberikan beberapa hal untuk perbaikan kedepannya. Untuk itu peneliti menyarankan kepada pihak-pihak tertentu yang berkepentingan dengan hasil penelitian ini, diantaranya:

1. Walaupun peran wali kelas secara daring maupun tatap muka sama akan tetapi lebih baik dilaksanakan secara tatap muka.

2. Semoga pembelajaran secara daring tidak berlangsung lama karena akan lebih banyak siswa kita yang dirugikan.

3. Bagi guru bidang studi, janganlah kamu melimpahkan semua permasalahan siswa kepada wali kelas, mari sama-sama menindaklanjuti permasalahan siswa tersebut. Kunci permasalahan siswa sebenarnya ada pada guru bidang studi masing-masing, dikarenakan wali kelas menunggu tanggapan dan data dari para guru bidang studi.

4. Bagi siswa, wali kelas hanya bisa memotivasi, menasehati terlepas dari keinginan dan minat itu kembali kepada siswanya masing-masing.

5. Bagiorangtua, mari kita mengawasi dan mengontrol anak kita apalagi kondisi sekarang anak kita sekarang berada dirumah didalam pengawasan bapak/ibu. 
Hal : $1-6$

\section{Daftar Pustaka}

[1] Siregar, S.U. (2016). Perbedaan Kemampuan Pemecahan Masalah Matematika Menurut Teori Belajar Bruner dan Teori Belajar Vigosky pada Kompetensi Dasar Menghitung Luas dan Keliling Bangun Datar kelas V Semester 2 SD Negeri 114375 Binaraga Rantauprapat. Jurnal Pembelajaran dan Matematika Sigma (JPMS). Vol. 2 No.2, hlm. 51-53. 2016

[2] Aditia,A.M. (2017). Pengaruh Penggunaan Internet Sebagai Media Belajar Terhadap Prestasi Belajar Mahasiswa Jurusan Administrasi Niaga. Politeknik Negeri Jakarta. Jurnal Epigram, Vol.14 No.1. 2017.

[3] Ashram, H. 2013. Peran Wali kelas dalam membentuk perilaku siswa di SD Negeri 7 Bungtiang.

[4] Choiroh, Nisaul. 2020, Efektifitas Pembelajaran Berbasis Daring/ E-Learning Dalam Pandangan Siswa [https://iain-surakarta.ac.id/\%EF\%BB\%BFefektifitas-pembelajaran-berbasis-daring-e-learning-dalampandangan-siswa/], (Diterbitkantanggal 23 Juni 2020)

[5] Albetus Adit. 2020, 12 Aplikasi Pembelajaran Daring Kerjasama Kemendikbud, Gratis! [https://edukasi.kompas.com/read/2020/03/22/123204571/12-aplikasi-pembelajaran-daring-kerjasamakemendikbud-gratis?page=all]. (diakses Kompas.com-22/03/2020, 12:32 WIB).

[6] Yantina, Debora. 2020, SE Dikti: MasaBelajarDiperpanjang 1 SementerAkibat Corona. [https://tirto.id/sedikti-masa-belajar-diperpanjang-1-sementer-akibat-corona-eKqH. Update Corona 12 April: 4.241 Positif, 373 Meninggal, 359 Sembuh] (diakses pada tanggal 4 April 2020).

[7] Suryani, Eli. 2018. Peran Wali Kelas Dalam Mengatasi Masalah Kesulitan Belajar Siswa di MIN Glugur Darat II Kecematan Medan Timur Tahun Ajaran 2017/2018. Universitas Islam Negeri Medan 
